\author{
유기셀레늄 혼합제 급여가 비육말기 거세한우의 성장, 도체성적, \\ 체내 셀레늄 분포 및 경제성에 미치는 영향 \\ 김동균 · 정다운 · 성하균 \\ 상지대학교 생명자원과학대학
}

\title{
Effects of Organic Selenium Mix on the Performance, Carcass Characteristics, Tissue Selenium Distribution, and Economic Value in Finishing Hanwoo Steers
}

\author{
D. K. Kim, D. U. Jung and H. G. Sung \\ College of Life Science and Natural Resources, Sang Ji University
}

\begin{abstract}
This study fulfilled to investigate the feed efficiency, tissue selenium distribution, carcass characteristic and economic value in finishing Hanwoo steers fed organic selenium mix (OSM) which included seleno-yeast, rumen culture and other microbial supplements. Forty five finishing Hanwoo steers were tested for 4 months dividing to three feeding groups: OSM add as $0.5 \mathrm{ppm}$ Se of DM feeds (0.5 ppm OSM), OSM enriched add as $1.0 \mathrm{ppm}$ Se of DM feeds (1.0 ppm OSM) and basal diet without OSM (control). The total weight gains, the average daily gains and the feed intakes were not differ in treatments $(p>0.05)$. No differences $(p>0.05)$ were noted for hot carcass weight, loin eye area, backfat thickness, meat yield index, meat color, fat color, tenderness and maturity. However, the $1.0 \mathrm{ppm}$ OSM showed better performances for feed requirement, TDN per gain, meat yield grade and meat quality grade compared to other groups. Tissue selenium distribution was increased by organic selenium feeding: higher Se concentration in liver and rump of $0.5 \mathrm{ppm}$ OSM $(\mathrm{p}<0.05)$, and kidney, liver, sirloin and rump of $1.0 \mathrm{ppm}$ OSM $(\mathrm{p}<0.05)$ than the tissues of control group. Generally, tissue selenium was the highest value in $1.0 \mathrm{ppm}$ OSM and showed higher concentrate in order; kidney, liver, sirloin and rump. The income over feed cost was 1.06 -fold higher in $1.0 \mathrm{ppm}$ OSM than control group. In conclusion, organic selenium mix supplementation and its amounts were not influenced to feed intake, body gain and carcass characteristic but significantly increased tissue selenium. Therefore, these results suggest that finishing Hanwoo steer fed an enriched organic selenium mix with proper probiotics is able to produce "high-Se" beef as high bioavailable form as well as create a beneficial opportunity on Hanwoo farm.

(Key words : Organic selenium, Seleno-yeast, Probiotics, Rumen culture, Hanwoo steers)
\end{abstract}

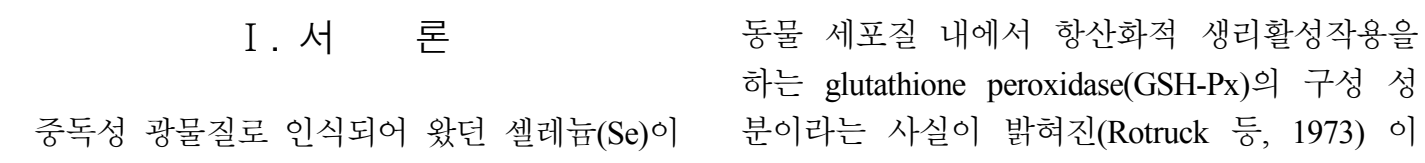

Corresponding author: D. K. Kim, Dept. of Animal Science \& Technology, College of Life Science and Natural Resources, Sangji University, Wonju, Korea. 220-702

Tel : 033-730-0532 E-mail : dkkim@mail.sangji.ac.kr. 
후, 이 원소가 병원균이나 악성종양에 대응하 는 다양한 면역계의 효율적 작용을 위한 필수 미량광물질로서의 기능과 역할이 구명되고 있 다(Arthur 등, 2003).

실험쥐에게 셀레늄을 요구량의 3 4배 급여하 였을 때 직장암 발생률이 감소하였으며(Finley 등, 2000), 유기셀레늄을 1 일 $200 \mu \mathrm{g}$ 수준으로 장 기간 복용한 사람들의 암 발병률이 낮았다(Clark 등, 1996). 또한 필수적 영양 성분 중 $\mathrm{Ca}, \mathrm{Fe}$, $\mathrm{I}$ 그리고 $\mathrm{Se}$ 와 같은 미네랄을 강화한 기능성 육제품과 유제품은 신생아 및 노약자의 면역 기능 증진 및 건강유지에 큰 도움을 줄 것이 다(Knowles 등, 1999). 비교적 풍부한 셀레늄을 사람에게 공급하는 단일 식품 품목으로 소고기 와 밀이 있으며(Schubert 등, 1987; Hintze 등, 2001), 육우의 근육 내 함유되어 있는 셀레늄은 인체 내에서 생리적 이용성이 높은 형태를 갖 고 있다(Shi와 Spallholz, 1994).

토양에 셀레늄이 많은 지역에서 사육된 육우 의 근육 내 셀레늄 함량이 다른 지역보다 높았 는데, 그 이유는 이 지역에서 자란 높은 농도 의 셀레늄을 함유한 조사료를 먹고 자랐기 때 문이다(Hintze 등, 2002). 이러한 연구 결과는 셀레늄을 증강한 사료를 급여하여 생리활성이 좋은 셀레늄 함량이 높은 육우를 생산할 수 있 는 가능성을 시사하는 것이다. 일반적으로, 사 료에 첨가하는 셀레늄으로는 무기태의 sodium selenate 또는 selenite을 사용하고 있으나 반추 동물의 경우, 반추위 미생물의 환원 작용 때문 에 흡수 및 이용효율이 단위동물에 비하여 매 우 낮은 편이다(Wright와 Bell, 1966). 따라서 반 추동물을 위한 셀레늄 첨가형태로 유기태 셀레 늄의 활용에 대한 관심이 높아지고 있다. 최근 의 연구에서, seleno-yeast를 사료에 첨가하여 급여한 우군에서 태어난 송아지의 셀레늄 영양 상태가 증진되었으며(Gunter 등, 2003), 우유 내 셀레늄의 함량이 무기태 셀레늄을 급여한 유 우보다 높았다(Ortman과 Pehrson, 1997)는 보고 가 있었고, Knowles 등(1999)은 sodium selenate $\left(\mathrm{Na}_{2} \mathrm{SeO}_{4}\right)$ 보다 유기태 셀레늄(oganic selenized yeast) 급여시 혈액, 우유 및 간에서 셀레늄 농 도와 glutathione peroxidase 활성이 높았으며 특
히, 유기태 셀레늄 급여시 우유로 전환되는 효 율은 무기태 셀레늄을 급여할 때보다 2 3배나 높았다고 보고하였다. 이와 같이 반추동물에 대한 셀레늄 공급형태로 유기태 셀레늄의 우수 성이 밝혀지고 있으나 한우에 대한 연구는 매 우 제한적으로 이루어지고 있어서 더 심도 있 는 연구가 필요한 상황이다.

이 연구는 유기태 셀레늄 급여가 한우의 생 산성에 미치는 영향을 알아보기 위하여 유기셀 레늄 혼합제의 첨가량을 달리하여 비육말기 거 세한우에 급여하였을 때 나타나는 증체효과, 도체성적, 체내 셀레늄 분포 및 경제성을 분석 평가하고자 실시하였다.

\section{II. 재료 및 방법}

\section{1. 공시축 및 실험설계}

본 연구는 강원도 횡성군에 소재한 한우사육 농가에서 배합사료와 볏짚을 중심으로 사육되 어 온 한우 중 건강상태가 양호하고 연령과 체 중이 유사한 비육말기 거세한우 45 두를 공시하 여 셀레늄 급여수준을 달리한 조건에서 4 개월 간 사양시험을 실시하였다.

공시축은 대조구, 시험1구 $(\mathrm{Se}$ 권장수준의 5 배), 시험 2 구 $(\mathrm{Se}$ 권장수준의 10 배) 등 3 개 구로 나누어 시험구별 15 두씩 임의배치 하였으며, 유기태 셀레늄 공급은 seleno-yeast를 혼합하여 조제한 국산 유기셀레늄 혼합제(organic selenium $\mathrm{mix}, \mathrm{OSM}$ )를 사용하였다. 시험구의 셀레늄 급여 수준은 사료건물 중 $\mathrm{Se}$ 함량이 각각 $0.5 \mathrm{ppm}$ 및 $1.0 \mathrm{ppm}$ 이 되도록 유기셀레늄 혼합제를 배 합하여 설정하였으며 대조구는 유기셀레늄 혼 합제를 급여하지 않았다.

\section{2. 유기셀레늄 혼합제 및 시험사료}

사양시험 기간 동안 공시축에게 급여하기 위 한 유기태 셀레늄으로 seleno-yeast $(1,100 \mathrm{ppm} \mathrm{Se}$ 건물 기준)와 미생물 제제 $(30 \%$ 반추미생물 배 양물, $10^{7} \mathrm{CFU}$ 이상의 유익 Bacillus 종, $30 \%$ 효모 배양물 그리고 기타 부형제 등을 포함)를 
혼합한 국내산 유기셀레늄 혼합제[OSM, (주)아 람루멘시스템]를 사용하였다.

시험기간 중 모든 시험구에 급여한 기초사료 로 조사료는 농가에서 자가생산한 녹색볏짚을 이용하였으며 농후사료는 지역배합사료공장에 서 생산한 비육말기 전용사료를 이용하였는데 일반성분과 에너지가는 Table 1과 같다.

Table 1. Chemical composition and energy value of experimental feeds(on dry matter basis)

\begin{tabular}{lcc}
\hline \multicolumn{1}{c}{ Item } & Rice straw & Formulated mix $^{\mathrm{a}}$ \\
\hline \hline Chemical composition $(\%)$ & \\
Dry Matter & 92.68 & 89.05 \\
Crude protein & 3.51 & 14.52 \\
Crude fat & 1.97 & 6.63 \\
Crude fiber & 31.39 & 4.18 \\
Crude ash & 12.03 & 7.78 \\
N.F.E. & 51.10 & 66.90 \\
Energy value & & \\
$\mathrm{TDN}^{\mathrm{b}}$ (\%) & 48.57 & 89.80 \\
$\mathrm{ME}^{\mathrm{c}}$ (Mcal/kg) & 1.76 & 3.24 \\
$\mathrm{NEm}^{\mathrm{d}}$ (Mcal $\left./ \mathrm{kg}\right)$ & 0.92 & 2.23 \\
$\mathrm{NEg}^{\mathrm{e}}$ (Mcal $\left./ \mathrm{kg}\right)$ & 0.37 & 1.54 \\
\hline
\end{tabular}

${ }^{\text {a }}$ Commercially mixed concentrates from Nonghyupfeed Co., Ltd.

${ }^{b}$ Predicted from Alderman(1985).

${ }^{c}$ Predicted from Alderman(1985) for compound feed and NRC(1988) for low quality roughage.

d, e Predicted from NRC (1988).

\section{3. 사양관리}

한우사육농가는 해발 $450 \mathrm{~m}$ 지점에 위치하였 으며, 각각의 실험우군은 동남향의 개방형 톱 밥운동장 우사에서 $10 \mathrm{~m}^{2}$ 두 수준의 수용밀도를 유지하여 사육하였다.

시험 우군의 관리는 거세한우 비육우 사양관 리의 관행지침에 따랐다. 기초사료로는 비육말 기 배합사료와 녹색볏짚을 평균 $5.0 \sim 5.5: 1.0$ (건물기준)으로 급여하였으며 유기태 셀레늄 급 여 시험구는 유기셀레늄 혼합제를 사료위에 뿌 려주는 방법(top dressing method)으로 첨가하였
다. 물은 자동급수를 통하여 자유롭게 먹을 수 있도록 하였다.

\section{4. 조사항목 및 분석방법}

공시 사료의 품질 평가를 위한 일반조성분 분 석은 $\mathrm{AOAC}(1995)$ 법을 이용하였고, $\mathrm{TDN}, \mathrm{ME}$, $\mathrm{NEm}$ 그리고 $\mathrm{NEg}$ 는 $\mathrm{Aderman}(1985)$ 과 $\mathrm{NRC}(1988)$ 의 추정공식을 적용하여 계산하였다. 체중과 증체량은 사양시험 시작일과 종료일 오전 10시 에 체중을 측정하여 증체량을 조사하였다. 사 료섭취량은 급여량과 잔량을 기준으로 측정하 였고, 사료효율은 사료섭취량을 증체량으로 나 누어 산정하였다.

사양시험 종료 후 인근 도축장에서 공시축을 도살한 후 도체성적을 조사하였는데 각 항목은 입회한 등급판정사가 농림부고시 축산물등급판 정세부기준(농림부, 2001)에 의거하여 평가한 것 을 반영하였다. 체조직의 셀레늄 함량을 측정하 기 위하여 신장, 간, 등심 그리고 우둔 부분에서 각각 다른 3 부위로부터 총 $300 \mathrm{~g}$ 이상의 조직 을 채취하고 혼입된 지방 조직을 제거한 후 완전히 갈아 $-70^{\circ} \mathrm{C}$ 에 보관하였다. 각 부위의 샘플은 Kimbrough와 Wakakuwa(1989)의 방법 에 따라 $1 \mathrm{~g}$ 을 취하여 $95^{\circ} \mathrm{C}$ 에서 nitric acid 로 소화시켜 $30 \%$ Hydogen peroxide로 처리한 후 플라즈마 질량분석기(ICP-MS, Ultramass 700, Varian)를 이용하여 셀레늄 함량을 측정하였다. 그리고 최종적으로 실험구간의 시험 결과가 현 실적으로 지니는 경제적 효과를 알아보기 위하 여 시험당시 도체경략가격과 공시한 단미사료의 시세를 적용하여 경제성을 분석하였다.

\section{5. 통계처리}

시험기간 중 수집된 개체별 측정기록은 개체 를 명시하여 기록 관리하였으며, 시험 종료 후 누적된 성적은 성장, 육질, 체내 셀레늄 분포 및 경제성을 평가하기 위하여 처리구별 조사항 목에 따라 분류하여 분석하였다. 사양시험에서 얻은 측정치는 $\mathrm{SAS}$ (Statistical Analysis System, Version 6.0, USA, 1995) package program을 이 
용하여 분석하였으며, 평균치의 처리간 유의성 은 F-test에서 유의성이 인정되는 $(\mathrm{P}<0.05)$ 결과 들에 대하여 LSD test를 이용하여 다중검정을 실시하였다.

\section{III. 결과 및 고찰}

\section{1. 증체율 및 사료이용 효율}

비육말기 거세한우에게 사료건물 중 셀레늄 농도가 각각 $0.5 \mathrm{ppm}$ 및 $1.0 \mathrm{ppm}$ 이 되도록 유기 셀레늄 혼합제(OSM)을 급여한 사양성적은 Table 2 와 같다. 각 처리구별 사양초기 평균체중은 542 (대조구), $546(0.5 \mathrm{ppm} \quad \mathrm{OSM}$ 구) 및 $547 \mathrm{~kg}(1.0$ $\mathrm{ppm} \mathrm{OSM}$ 구)으로 처리구간 평균 체중이 거의 같은 수준이 되도록 임의배치 하였으며, 이들 공시 한우에게 4 개월간 유기셀레늄 혼합제를 급여한 결과 시험 종료시 체중은 $0.5 \mathrm{ppm} \mathrm{OSM}$ 과 $1.0 \mathrm{ppm} \mathrm{OSM}$ 시험구가 각각 $625 \mathrm{~kg}$ 과 631 $\mathrm{kg}$, 그리고 유기셀레늄을 급여하지 않은 대조 구는 $623 \mathrm{~kg}$ 이었다. 이와 같이 유기셀레늄 혼 합제 급여구의 시험 종료시 체중이 대조구에 비하여 다소 높았으나 실제적으로 시험 기간 동안 증가한 총 증체량은 대조구의 $81 \mathrm{~kg}$ 에 비 하여 $0.5 \mathrm{ppm} \mathrm{OSM}$ 시험구가 $79 \mathrm{~kg}$ 으로 $3 \mathrm{~kg}$ 정 도 낮았으며, $1.0 \mathrm{ppm} \mathrm{OSM}$ 시험구는 $84 \mathrm{~kg}$ 으로 $3 \mathrm{~kg}$ 정도 높았다. 그러나 이들 수치적 차이는
시험구간 통계적 의미를 갖지 못하였다 $(\mathrm{p}>$ 0.05). 따라서 대조구, $0.5 \mathrm{ppm} \mathrm{OSM}$ 구 및 1.0 $\mathrm{ppm} \mathrm{OSM}$ 구의 일일 두당 증체량은 각각 0.68 $\mathrm{kg}, 0.66 \mathrm{~kg}$ 및 $0.71 \mathrm{~kg}$ 으로 나타나 유기셀레늄 의 급여와 급여 수준은 체중 증가에 영향을 주 지 못하였다 $(\mathrm{p}>0.05)$. 이 결과는 Lawler 등 (2004)이 알팔파와 밀에 있는 유기태 셀레늄과 sodium selenate을 이용하여 대조구 $(0.38 \mathrm{ppm})$ 에 비하여 다소 높은 수준 즉, $2.84,2.80$ 그리고 $2.86 \mathrm{ppm}$ 으로 급여하였을 때 각각 시험구간 증 체량의 차이가 없었다 $(\mathrm{p}>0.53)$ 고 보고한 사례와 유사하였다. 또한 Hintze 등(2002)도 고농도의 유기셀레늄(11.9 mg Se/kg feed)을 말기 거세 비 육우에게 105 일 급여하였을 때에도 시험 종료 시 체중과 일일 증체량에 차이가 없었다는 결과 와 같은 맥락을 나타낸 것이다. 이상의 결과를 종합할 때 비육말기 육우에게 셀레늄의 수준을 크게 높여 급여하더라도 증체성적에는 악 영향 을 주지 않음을 의미한다. 그러나 돼지의 경우 에는 셀레늄을 사료 중 $5.0 \mathrm{ppm}$ 에서 $20.0 \mathrm{ppm}$ 수 준으로 증가 급여하였을 때 시험 종료시 체중과 일일 증체량이 감소하였다는 보고도 있었다 $(\mathrm{Kim}$ 과 Mahan, 2001).

사료 섭취량에 있어서도 유기 셀레늄 급여 수준의 영향은 나타나지 않았다. 즉, 대조구, $0.5 \mathrm{ppm} \mathrm{OSM}$ 구 그리고 $1.0 \mathrm{ppm} \mathrm{OSM}$ 구의 조사 료 섭취량 $(\mathrm{kg} / \mathrm{head} / \mathrm{day})$ 은 1.67 에서 1.78 수준을

Table 2. Effect of organic selenium mix supplementation on weight gain and feed efficiency of Hanwoo steers

\begin{tabular}{lrrr}
\hline Item & \multicolumn{1}{c}{ Control } & 0.5 ppm OSM & 1.0 ppm OSM \\
\hline \hline Initial body weight $(\mathrm{kg})$ & $541.73 \pm 30.42$ & $546.13 \pm 30.37$ & $547.13 \pm 18.47$ \\
Final body weight (kg) & $622.79 \pm 33.88$ & $625.12 \pm 38.94$ & $631.45 \pm 26.67$ \\
Total weight gain (kg) & $81.06 \pm 12.47$ & $78.99 \pm 19.30$ & $84.32 \pm 15.27$ \\
Average daily gain (kg/head) & $0.68 \pm 0.10$ & $0.66 \pm 0.16$ & $0.71 \pm 0.13$ \\
Feed intake (DM basis, kg/head/day) & & & \\
$\quad$ Roughage intake & $1.67 \pm 0.41$ & $1.78 \pm 0.37$ & $1.71 \pm 0.41$ \\
Concentrate feed intake & $9.33 \pm 1.54$ & $9.34 \pm 1.16$ & $9.48 \pm 1.51$ \\
Total intake & $11.00 \pm 1.30$ & $11.12 \pm 0.87$ & $11.19 \pm 1.14$ \\
TDN intake (kg/head/day) & 9.19 & & 9.25 \\
Feed requirement & 16.18 & 16.85 & 9.35 \\
TDN/gain & 13.51 & 14.02 & 15.76 \\
\hline Values & & & 13.17 \\
\hline
\end{tabular}

Values are means \pm SE. 
보였으며 농후사료는 9.33 에서 9.48 수준으로 나타나 시험구간 차이가 없었고 $(\mathrm{p}>0.05)$, 총섭취 량 $(\mathrm{kg} / \mathrm{head} / \mathrm{day})$ 도 11.00 에서 11.19 정도의 수준으 로 시험구간 유사하였다 $(\mathrm{p}>0.05)$. 이 결과는 Gunter 등(2003)이 sodium slenite 또는 selenoyeast를 급여하였을 때와 급여하지 않았을 때 조사료 건물 섭취량에 차이가 없었다고 보고한 사례와 동일한 것이었다. 그러나 유기셀레늄 혼 합제로부터 섭취한 셀레늄 총량 $(\mathrm{mg} / \mathrm{head} / \mathrm{day})$ 은, $0.5 \mathrm{ppm} \mathrm{OSM}$ 구와 $1.0 \mathrm{ppm} \mathrm{OSM구는} \mathrm{각각} 5.56$ 과 11.19 로 실제 섭취한 량에 있어서도 시험설 계에서 의도한 바와 같이 유기셀레늄 혼합제 급여 처리군간 두 배의 차이를 보였다. 본 연 구와 같은 사료섭취량에 대한 결과는 다양한 셀레늄을 여러 가지의 농도로 급여한 비육우 (Hintze 등, 2002; Lawler 등 2004) 및 유우(Gierus 등, 2002) 시험에서도 보고된 바 있다. 사료요구량 과 증체당 $\mathrm{TDN}$ 섭취량(TDN/gain)은 $1.0 \mathrm{ppm} \mathrm{OSM}$ 구에서 15.76과 13.17로 대조구(16.18과 13.51)와 $0.5 \mathrm{ppm} \mathrm{OSM}$ 구 (16.85와 14.02)에 비하여 다소 유리한 경향을 보였다. 이러한 경향은 반추위 내용물 또는 유용 미생물들을 이용한 첨가제의 급여가 반추위 발효에 영향을 준다는 보고 (Krehbiel 등, 2003; Martin과 Nisbet, 1992)를 고려 할 때 유익 미생물(반추미생물 배양물, 효모 및 유익 Bacillus 종 등)을 함유한 유기셀레늄 혼합 제(OSM)의 충분한 급여는 반추 발효 효율을 증진 시킬 수 있는 부가적 효과를 시사하는 것 으로 추론할 수 있었다.

\section{2. 조직 내 셀레늄 함량}

유기셀레늄 혼합제 급여와 급여 수준이 조직 내 셀레늄의 함량에 미치는 영향은 Fig. 1 및 Fig.2와 같다. 신장과 간 내 셀레늄 함량의 변 화는 Fig. 1과 같으며, 신장에서는 유기셀레늄 혼합제 급여구의 셀레늄 함량이 대조구 $(1,462$ $\mathrm{ppb}$ )에 비하여 증가 하였다. 즉, $0.5 \mathrm{ppm} \mathrm{OSM구}$ 와 $1.0 \mathrm{ppm} \mathrm{OSM}$ 구의 신장 내 셀레늄 함량은 각각 1,470 과 $1,742 \mathrm{ppb}$ 로서 유기태 셀레늄 급 여량이 증가함에 따라 유의적으로 증가하였다 $(\mathrm{p}$ $<0.01)$. 간장 내 셀레늄의 함량은 대조구, 0.5
Fig. 1. Selenium concentration in kidney and liver by different amount of organic selenium.

$\mathrm{ppm} \mathrm{OSM}$ 구 및 $1.0 \mathrm{ppm} \mathrm{OSM}$ 구에서 각각 458, 660 및 $945 \mathrm{ppb}$ 로 $1.0 \mathrm{ppm} \mathrm{OSM}$ 구에서 가장 높 았다 $(\mathrm{p}<0.01)$. 간의 경우에도 신장에서와 같이 유기 셀레늄 공급으로 조직 내 셀레늄의 함량 이 증가하였고 유기셀레늄 혼합제 공급량에 의하여도 차이를 나타냈다.

본 연구와 유사한 결과로 Lawler 등(2004)은 식물(밀)유래 유기태 셀레늄을 비육말기 거세우 에게 급여하였을 때 신장과 간장의 셀레늄 농 도가 각각 12.89 와 $10.79 \mathrm{ppm}$ 으로서 급여하지 않은 우군(각각 8.40 과 $2.33 \mathrm{ppm}$ )에 비하여 증가 하였으며, 급여원에 따라 즉 대조구, sudium selenate, 알팔파 유래 유기태 셀레늄 그리고 밀 유래 유기태 셀레늄 순으로 장기조직 내 셀레 늄 함량이 높아졌다고 하였다(신장 : $8.40<10.05$ $<10.86<12.89 \mathrm{ppm}$; 비장 : $2.00<2.60<3.82<5.16$ $\mathrm{ppm} ; \mathrm{p}<0.01)$. 또한 유기태 셀레늄 급여로 간 조직 내 셀레늄이 증가하였다는 결과도 Knowles 등(1999)에 의하여 보고된 바 있다. 이와 같이 유기 셀레늄 급여는 신장과 간 조직의 셀레늄 함량뿐만 아니라 비장, 모피 그리고 혈장의 셀 레늄 함량에 영향을 주며(Banuelos와 Mayland, 2000 ; Lawler 등, 2004), 간과 혈액 내 glutathione peroxidase(GSH-Px)의 활성을 증가 시켰다(Knowles 등, 1999; Gunter 등, 2003). Glutathione peroxidase $(\mathrm{GSH}-\mathrm{Px})$ 는 세포질 내에서 항산화적 생리활성 작용으로 면역계 기능의 효율을 증진시키는 것 
으로 잘 알려져 있다(Arthur 등, 2003).

근육 조직 내 셀레늄 함량으로 등심과 우둔 의 셀레늄 함량은 Fig. 2와 같다. 대조구, 0.5 $\mathrm{ppm} \mathrm{OSM}$ 구 그리고 $1.0 \mathrm{ppm} \mathrm{OSM}$ 구의 등심 중 셀레늄 함량은 각각 116,135 및 $161 \mathrm{ppb}$ 로 유 기셀레늄 혼합제 첨가와 첨가량 증가에 따라 등심 조직 내 셀레늄 함량이 증가되는 경향을 보였으며 특히, 고농도의 유기태 셀레늄 공급 $(1.0 \mathrm{ppm} \mathrm{OSM})$ 은 근육 내 셀레늄 증강에 큰 효 과를 나타냈다 $(\mathrm{p}<0.01)$. 그리고 우둔의 경우에 도 근육 내 셀레늄 함량은 $0.5 \mathrm{ppm} \mathrm{OSM}$ 구 및 $1.0 \mathrm{ppm} \mathrm{OSM}$ 구가 각각 118 과 $123 \mathrm{ppb}$ 로 급여 하지 않은 대조구 $(87 \mathrm{ppb})$ 에 비하여 유의적으로 증가하였다 $(\mathrm{p}<0.01)$. 그러나 등심과 우둔 모두 에서 유기태 셀레늄의 급여량 증가에 따른 근 육 내 셀레늄 함량의 차이는 통계적으로 인정 되지 않았으나 급여수준의 증가가 근육내 셀레 늄함량을 증가시키는 경향을 보였다. 이상과 같 은 결과는 Allaway (1973)와 Van Ryssen 등 (1989)이 면양을 대상으로 한 사양시험에서도 보고 된 바 있으며, 이들은 이러한 근육 내 셀 레늄 함량의 증진효과는 무기태 셀레늄보다 유 기태 셀레늄 공급에 의해 더 크게 나타났다고 보고하였다. 그리고 Lawler 등(2004)도 비육 말 기 육우에서 유기태 셀레늄을 급여하지 않은 대조구의 근육 내 셀레늄(1.33 ppm)에 비하여 유 기태 셀레늄 급여 우군의 근육 내 셀레늄 (3.32-4.41 ppm)이 증가한다고 보고하였다. Combs 와 $\operatorname{Combs}(1986)$ 는 일반적으로 조직 셀레늄의 함 량이 신장에서 가장 높고 다음에 간장 그리고 근육 순으로 낮았다고 보고하였는데 이와 같은 경향은 본 연구에서도 나타났다(Fig. 1과 2). 또한 Lawler 등(2004)도 비육 말기 육우의 조직들(신장 간장 그리고 간장)에서 유사한 셀레늄 함량(각각 $10.86 \sim 12.98,6.56 \sim 10.79$ 그리고 $3.32-4.41 \mathrm{ppm})$ 의 경향을 보고하였다.

본 연구에서, 고농도 유기셀레늄을 함유한 유기셀레늄 혼합제를 사료 중 $1.0 \mathrm{ppm}$ 수준으로 급여한 한우육을 식용할 경우, 등심과 우둔으 로 각 $100 \mathrm{~g}$ 씩 먹는다면 생체내 이용효율이 높은 셀레늄을 $28.4 \mu \mathrm{g}$ 섭취한 결과가 되며, 간 $100 \mathrm{~g}$ 을 먹는다면 $94.5 \mu \mathrm{g}$ 의 셀레늄을 섭취하게 된다.
Fig. 2. Selenium concentration in sirloin and rump by different amount of organic selenium.

Shi와 Spallholz (1994)은 사람을 위하여 일반 적으로 공급되는 셀레늄 형태인 selenite와 selenate 그리고 소고기로부터 제공된 셀레늄을 쥐에게 급여하였을 때 소고기 유래 유기태 셀 레늄의 생체 이용률이 더 높았다고 보고하였 다. 따라서 유기셀레늄 보강 사양으로 생산된 한우 고기는 생물이용성이 좋은 유기셀레늄 강 화 육제품의 생산 가능성을 시사한다.

\section{3. 도체성적}

유기태 셀레늄 급여에 의한 도체특성에 미치 는 영향은 Table 3 과 같다. 비육말기 거세한우 의 시험 종료시 대조구, $0.5 \mathrm{ppm} \mathrm{OSM}$ 구 및 $1.0 \mathrm{ppm} \mathrm{OSM}$ 구의 도체중량은 각각 384,388 및 $389 \mathrm{~kg}$ 으로 나타났으나 이들 시험구간 성적 의 통계적 의미는 없었다 $(\mathrm{p}>0.05)$. 배최장근면 적도 대조구와 $0.5 \mathrm{ppm} \mathrm{OSM}$ 구에서는 $84 \mathrm{~cm}^{2}$ 인데 비하여 $1.0 \mathrm{ppm} \mathrm{OSM구는} 89 \mathrm{~cm}^{2}$ 으로 높았 으나 통계적 유의성이 인정되지 않았으며, 등 지방 두께는 9.3 에서 $10.1 \mathrm{~mm}$ 의 범위로 유사하 였다. 그리고 육량지수는 모든 시험구에서 공 히 68 정도로 유사하였다. 이 밖의 도체 특성 으로서 육색지수, 지방색 및 성숙도는 모든 시 험구에서 각각 $4.9,3.0$ 및 2.0 정도의 수준으로 처리구간 차이를 보이지 않았다. 이와 유사한 연구 결과로 Lawler 등(2004)는 43두의 비육말 
Table 3. Carcass characteristics of Hanwoo steers fed organic selenium mix for 4 months

\begin{tabular}{|c|c|c|c|}
\hline Item & Control & 0.5 ppm OSM & 1.0 ppm OSM \\
\hline \multicolumn{4}{|l|}{ Yield traits } \\
\hline Carcass weight (kg) & $384.40 \pm 23.28$ & $388.40 \pm 24.69$ & $389.93 \pm 5.04$ \\
\hline Loin eye area $\left(\mathrm{cm}^{2}\right)$ & $84.80 \pm 6.00$ & $84.13 \pm 5.99$ & $89.33 \pm 7.47$ \\
\hline Backfat thickness (mm) & $9.40 \pm 2.56$ & $10.13 \pm 2.06$ & $9.26 \pm 2.45$ \\
\hline Meat yield index & $68.53 \pm 1.22$ & $68.20 \pm 0.96$ & $68.80 \pm 4.00$ \\
\hline Meat yield grade $(\mathrm{A}: \mathrm{B}: \mathrm{C})$ & $(5: 10: 0)$ & $(4: 10: 1)$ & $(6: 9: 0)$ \\
\hline \multicolumn{4}{|l|}{ Quality traits } \\
\hline Meat color & $4.86 \pm 0.23$ & $4.86 \pm 0.35$ & $4.93 \pm 0.12$ \\
\hline Fat color & $3.00 \pm 0.00$ & $3.00 \pm 0.00$ & $3.00 \pm 0.00$ \\
\hline Tenderness & $1.33 \pm 0.44^{\mathrm{a}}$ & $1.40 \pm 0.48^{\mathrm{a}}$ & $1.00 \pm 0.00^{\mathrm{b}}$ \\
\hline Maturity & $2.00 \pm 0.00$ & $2.00 \pm 0.00$ & $2.00 \pm 0.00$ \\
\hline $\begin{array}{l}\text { Meat quality grade } \\
\left(1^{+}: 1: 2: 3\right)\end{array}$ & $(5: 5: 5: 0)$ & $(3: 6: 5: 1)$ & $(7: 8: 0: 0)$ \\
\hline
\end{tabular}

Values are means \pm SE.

a, $b$ Value with different superscripts in the same row differ at $\mathrm{P}<0.05$.

기의 거세우에게 셀레늄의 종류(무기태와 유기 태 셀레늄)와 수준 $\left(0.38^{\sim} 2.86 \mathrm{ppm}\right)$ 을 다양하게 126 일 동안 급여하였을 때 도체중량, 근단면적, 등지방두께, 근내지방도 등에서 대조구와 처리 구간에 차이가 없었다 $(\mathrm{p}>0.12)$ 고 보고하였다.

또한 같은 연구에서 Lawler 등(2004)은 도체 등급 $(\mathrm{p}>0.12)$ 과 근내지방등급 $(\mathrm{p}>0.19)$ 에 있어 서도 유기태 셀레늄 또는 무기태 셀레늄 급여 에 의해 영향을 받지 않았다고 보고하였다. 그 러나 본 연구에서는 도체등급, 연도 및 육질등 급이 $1.0 \mathrm{ppm} \mathrm{OSM}$ 구에서 가장 좋게 나타났다. 즉, 도체 등급(A:B:C)이 대조구와 $0.5 \mathrm{ppm} \mathrm{OSM}$ 구가 각각 $5: 10: 0$ 과 $4: 10: 1$ 를 나타낸 것에 비하 여 $1.0 \mathrm{ppm} \mathrm{OSM}$ 구에서 6:9:0으로 좋은 등급을 기록하였으며, 연도는 $1.0 \mathrm{ppm} \mathrm{OSM}$ 구에서 1.0 으로 대조구와 $0.5 \mathrm{ppm} \mathrm{OSM}$ 구의 1.3 과 1.4 에 비하여 낮은 수치를 보였다 $(\mathrm{p}<0.05)$. 그리고 육질등급 $\left(1^{+}: 1: 2: 3\right)$ 은 대조구와 $0.5 \mathrm{ppm}$ OSM 구 가 각각 $5: 5: 5: 0$ 과 $3: 6: 5: 1$ 인데 비하여 $1.0 \mathrm{ppm}$ $\mathrm{OSM}$ 구에서 7:8:0:0으로 크게 향상된 결과를 나타냈다.

\section{4. 경제성}

본 연구에서 해당기간 중 발생한 경제적 효 과를 알아보기 위하여 유기셀레늄 혼합제 급여
구 $(0.5$ 와 $1.0 \mathrm{ppm} \mathrm{OSM})$ 와 대조구의 평균 성적 을 근거로 사양시험 종료시 지육경락가와 사료 비를 적용하여 경제성을 분석하였던 바 그 결 과는 Table 4와 같다.

사료섭취량(Table 2)은 세 개의 처리구 공히 $11 \mathrm{~kg} / \mathrm{head} / \mathrm{day}$ 정도의 수준으로 두당 사료비는 대조구와 유기셀레늄 혼합제 급여구 사이에 큰 차이는 없었고, 두당 지육경락가는 대조구, $0.5 \mathrm{ppm} \quad \mathrm{OSM}$ 구 및 $1.0 \mathrm{ppm} \quad \mathrm{OSM}$ 구가 각각 825,330 원, 809,985 원 및 860,970원으로 유기셀 레늄 혼합제 $1.0 \mathrm{ppm}$ 급여구가 가장 높았다. 따 라서 사료비를 공제한 두당 소득은 대조구에 비하여 $0.5 \mathrm{ppm}$ OSM구가 18,720 원이 낮았지만 $1.0 \mathrm{ppm} \mathrm{OSM}$ 구에서는 30,999원이 많았다. 이들 소득액을 지수로 환산하면 $0.5 \mathrm{ppm} \mathrm{OSM구는}$ 대조구에 비하여 $3.3 \%$ 가 낮은 반면 $1.0 \mathrm{ppm}$ $\mathrm{OSM}$ 구는 $5.5 \%$ 가 많았음을 의미한다. 각 시험 구의 사료비가 유사한 가운데 $1.0 \mathrm{ppm} \mathrm{OSM}$ 시 험구에서 나타난 이러한 경제적 이윤은 미생물 첨가제가 비육우 생산 및 도체특성에 좋은 영향 을 준다는 Krehbiel 등(2003)과 $\operatorname{Mir}$ 와 $\operatorname{Mir}(1994)$ 의 보고를 고려할 때 본 시험에서 사용한 유기셀 레늄 혼합제도 이와 유사한 부가적 효과의 가 능성이 있음을 시사한다.

셀레늄은 면역계 작용과 관련하여 그 기능과 역할이 잘 알려져 있고(Brown과 Arthur, 2001; 
Table 4. Prediction of economic value in Hanwoo steers fed organic selenium mix for 4 months

\begin{tabular}{|c|c|c|c|}
\hline Item & Control & 0.5 ppm OSM & 1.0 ppm OSM \\
\hline Carcass production $^{\mathrm{a}}(\mathrm{kg} / \mathrm{head})$ & 50.02 & 49.09 & 52.18 \\
\hline Income from carcass ${ }^{b}(W /$ head $)$ & 825,330 & 809,985 & 860,970 \\
\hline Feed $\operatorname{cost}^{\mathrm{c}}(W /$ head $)$ & 265,308 & 268,683 & 269,949 \\
\hline Gross profit per head ${ }^{\mathrm{d}}$ & 560,022 & 541,302 & 591,021 \\
\hline Profit index & 100 & 96.7 & 105.5 \\
\hline Profit difference $(W /$ head) & 0 & $-18,720$ & $+30,999$ \\
\hline
\end{tabular}

${ }^{a}$ Weight gain $\times$ dressing percentage(carcass weight $\div$ final body weight $\times 100$ ).

${ }^{b}$ Calculated from market price of carcass $(W 16,500 / \mathrm{kg}$ for A1 grade) at December 15. 2002.

c Applied the unit price of rice $\operatorname{straw}(W 240 / \mathrm{kg})$ and concentrate $(W 196 / \mathrm{kg})$.

d Income from carcass - feed cost.

Arthur 등, 2003), 육우의 근육 내 셀레늄은 인 체 내에서 생리적 이용성이 높은 유기태 셀레 늄임(Shi와 Spallholz, 1994)을 고려할 때, 본 연 구의 결과는 유기태 셀레늄함량이 높은 고급 한우 생산을 통한 기능성 동물성 식품의 생산 가능성과 한우육의 경제적 부가가치 증진의 가능성을 시사한다.

\section{IV. 요 약}

본 연구는 유기태 셀레늄 급여가 한우의 생 산성에 미치는 영향을 연구하기 위하여 유기태 셀레늄 혼합제의 첨가량을 달리하여 비육말기 거세한우에 급여하였을 때 나타나는 성장, 육 질, 체내 셀레늄 분포 및 경제성을 분석 평가 하고자 실시하였다. 총 45 두의 비육후기 거세 한우를 유기태 셀레늄 혼합제 급여 수준에 따 라 15 두씩 3 개의 시험구에 임의배치 하고 사 료 건물 중 셀레늄 함량을 $0.5 \mathrm{ppm}$ 수준이 되 도록 유기셀레늄 혼합제를 급여한 시험구 $(0.5$ $\mathrm{ppm} \mathrm{OSM}$ 구), $1.0 \mathrm{ppm}$ 수준으로 처리한 시험구 (1.0 ppm OSM구) 및 대조구(혼합제 무첨가 관 행사육구)로 나누어 4 개월간 사양시험을 수행 한 결과는 다음과 같다. 3 개의 시험구간 총 증 체량, 일일 증체량 및 사료 섭취량의 통계적 유의성은 없었다 $(\mathrm{p}>0.05)$. 도체중량, 배최장근 면적, 등지방두께, 육량지수, 육색지수, 지방색, 연도, 성숙도 등에서도 시험구간 유의적 차이 가 인정되지 않았다 $(\mathrm{p}>0.05)$. 그러나 상대적으
로 유기태 셀레늄과 함께 미생물 제제가 많이 공급된 $1.0 \mathrm{ppm} \mathrm{OSM}$ 구에서 사료효율(사료요 구량과 증체당 $\mathrm{TDN}$ ), 도체등급 및 육질등급이 다른 시험구보다 좋은 성적을 나타냈다. 각 조 직의 셀레늄은 유기태 셀레늄 급여에 의해 함 량이 증가되었는데 $0.5 \mathrm{ppm} \mathrm{OSM}$ 구에서는 간 과 우둔 그리고 $1.0 \mathrm{ppm} \mathrm{OSM}$ 구에서는 신장, 간, 등심 및 우둔의 셀레늄함량이 대조구보다 높았다 $(\mathrm{p}<0.05)$. 조직 내 셀레늄 함량은 전반 적으로 $1.0 \mathrm{ppm} \mathrm{OSM}$ 구에서 가장 높게 나타났 으며, 각 조직간 셀레늄 함량은 신장, 간, 등심 그리고 우둔 순으로 높았다. 사양시험 종료시 도체 경락가를 기초로 경제성을 평가하였을 때 $1.0 \mathrm{ppm} \mathrm{OSM}$ 구가 대조구에 비하여 수익성이 $5.5 \%$ 정도 높았다. 결론적으로, 유기셀레늄 혼 합제의 급여와 급여수준은 사료섭취량, 증체량 그리고 도체특성에 큰 영향을 주지 않았지만 각 조직의 셀레늄 함량을 증가시켰다. 또한 유 기셀레늄 혼합제를 $1.0 \mathrm{ppm}$ 수준으로 사용하였 을 때 육우 판매수입이 증가하였다.

$$
\mathrm{V} \text {. 사 사 }
$$

이 논문은 2001년도 상지대학교 교내연구비 (연구년제)와 2002년도 횡성군의 학술용역 연구 비 및 아람루멘시스템(주)에서 생산한 시험재료 를 지원받아 이루어진 것으로, 이 지면을 빌어 감사의 뜻을 표합니다. 


\section{VI. 인 용 문 헌}

1. Aderman, G. 1985. Prediction of the energy of compound feeds. In recent advances in animal nutrition. Butterworths.

2. Allaway, W. H. 1973. Selenium in the food chain. Vet. 63(Soppl. 3):151-170.

3. Arthur, J. R., McKenzie, R. C. and Beckett, G. J. 2003. Selenium in the immune system. J. Nutr (Suppl):1457s-1459s.

4. Brown, K. M. and Arthur, J. R. 2001. Selenium, seleoproteins and human health: a review. Public. Health Nutr. 4:593-599.

5. Banuelos, G. S. and Mayland, H. F. 2000. Absorption and distribution of selenium in animal consuming canola grown for selenium phytoremediation. Ecotoxicol. Environ. Saf. 46:322-328.

6. Clark, L. C., Combs, G. F., Turnbull, B. W., Slate, E. H., Chalker, D. K., Chow, J., Davis, L. S., Glover, R. A., Gramham, E. G., Gross, E. G., Krongard, A., Lesher, J. L., Park, H. K., Sandes, B. B., Smith, C. L. and Taylor, J. R. 1996. Effect of selenium supplementation for cancer prevention in patients with carcinoma of the skin. JAMA (J. Am. Med. Assoc.) 276:1957-1962.

7. Comb, G. F. Jr. and Comb, S. B. 1986. The role of selenium in nutrition. Academic Press, Orlando, Florida.

8. Finley, J. W., Davis, C. D. and Feng, Y. 2000. Selenium from high selenium broccoli protects rats from colon cancer. J. Nutr. 130: 2384-2389.

9. Gierus, M., Schwarz, F. J. and Kirchgessner, M. 2002. Selenium supplementation and selenium status of dairy cows fed diets based on grass, grass silage or maize silage. J. Anim. Physiol. a. Anim. Nitr. 86:74-82.

10. Gunter, S. A., Beck, P. A. and Phillips, J. M. 2003. Effects of supplementary selenium source on the performance and blood measurements in beef cows and their calves. J. Anim. Sci. 81: 856-864.

11. Hintze, K. J., Lardy, G. P. Marchello, M. J. and Finley J. W. 2001. Areas with high concentrations of selenium in the soil and forage produce beef with enhanced concentrations of selenium. J. Agric. Food Chem. 49:1062-1067.

12. Hintze, K. J., Lardy, G. P., Marchello, M. J. and Finley, J. W. 2002. Selenium accumulation in beef: Effect of dietary selenium and geographical area of animal origin. J. Agric. Food Chem. 50: 3938-3942.

13. Kim, Y. Y. and Mahan, D. C. 2001. Comparative effects of high dietary levels of organic and inorganic selenium on selenium toxicity of growing-finishing pigs. J. Anim. Sci. 79:942-948.

14. Kimbrough, D. E. and Wakakuwa, J. R. 1989. Acid digestion for sediments, sludeges, soil, and solid wastes. Enviro.l Sci. Technol. 23:898.

15. Knowles, S. O., Grace, N. D., Wurms, K. and Lee, J. 1999. Significance of amount and form of dietary selenium on blood, milk, and casein selenium concentration on grazing cows. J. dairy Sci. 82:429-437.

16. Krehbiel, C. R., Rust, S. R. and Gilliland, S. E. 2003. Bacterial direct-fed microbials in ruminant dieet: Perfermance response and mode if action. J. Anim. Sci. 81(E. Suppl. 2):E120-E132.

17. Lawler, T. L., Taylor, J. B., Finley, J. W. and Caton, J. S. 2004. Effect of supranutritional and organically bound selenium on performance, carcass characteristics, and selenium distribution in finishing beef steers. J. Anim. Sci. 82:1488-1493.

18. Martin, S. A. and Nisbet, D. J. 1992. Effect of direct-fed microbials on rumen microbial fermentation. J, dairy Sci. 75:1736-1744.

19. Mir, Z. and Mir, P. S. 1994. Effect of the addition of live yeast (Saccharomyces cerevisiae) on growth and carcass quality of steers fed high-forage or high-grain diets on feed digestibility and in situ degradability. J, Anim. Sci. 72:537-545.

20. NRC. 1988. Nutrient requirements of domestic animals. Nutrient requirements of dairy cattle. 7th ed. Washington, National Academy Press.

21. Ortman, K. and Pehrson, B. 1997. Selnenite and selenium yeast as feed supplements for dairy cows. J. Vet. Med. A 44:373-380.

22. Rotruck, J. T., Pope, A. L., Ganther, H. E., Swanson, A. B., Hafman, D. G. and Hoekstra, W. 
G. 1973. Selenium; Biochemical role as a component of glutathione peroxidase. Science 179: 588-590.

23. SAS Institute, Inc. 1995. DAD. For Linear models: a guide to the ANOVA and GLM procedures. SAS. Inst. Inc., Cary, NC.

24. Schubert, A., Hoden, J. M. and Wolf, W. R. 1987. Selenium content of a core group of foods based on a critical evaluation of published analytical data. J. Am. Diet. Assoc. 87:285-299.

25. Shi, B. and Spallholz, J. E. 1994. Selenium from beef is highly bioavailable as assessed by liver glutathione peroxidase activity (EC 1.11.1.9) and tissue selenium. Br. J. Nutr. 72:873-881.
26. Steel, R. G. D. and Torrie, J. H. 1980. Principles and Procedure of Statistics: A Biometrical Approach 2nd ed MCGraw Hill Book Co., Inc., New York.

27. Van Ryssen, J. B. J., Deagen, J. T., Beilstein, M. A. and Whanger, P. D. 1989. Comparative metabolism of organic and inorganic selenium by sheep. J. Agric. Food Chem. 37:1358-1363.

28. Wright, P. L. and Bell, M. C. 1966. Comparative metabolism of selenium and tellurium in sheep and swine. Am. J. Physiol. 211:6-10.

(접수일자 : 2005. 8. 26. / 채택일자 : 2005. 11. 10.) 